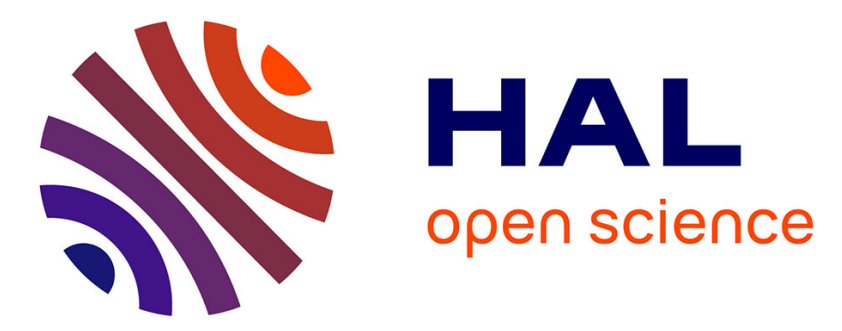

\title{
Microstructural Control of Mn-Zn Ferrite with Addition of Seed Grains
}

\author{
S. Doh, J. Park, J. Suk, H. Shon, J. Kim, W. Hur
}

\section{To cite this version:}

S. Doh, J. Park, J. Suk, H. Shon, J. Kim, et al.. Microstructural Control of Mn-Zn Ferrite with Addition of Seed Grains. Journal de Physique IV Proceedings, 1997, 07 (C1), pp.C1-59-C1-60. 10.1051/jp4:1997110 . jpa-00254720

\section{HAL Id: jpa-00254720 https://hal.science/jpa-00254720}

Submitted on 1 Jan 1997

HAL is a multi-disciplinary open access archive for the deposit and dissemination of scientific research documents, whether they are published or not. The documents may come from teaching and research institutions in France or abroad, or from public or private research centers.
L'archive ouverte pluridisciplinaire HAL, est destinée au dépôt et à la diffusion de documents scientifiques de niveau recherche, publiés ou non, émanant des établissements d'enseignement et de recherche français ou étrangers, des laboratoires publics ou privés. 


\title{
Microstructural Control of Mn-Zn Ferrite with Addition of Seed Grains
}

\author{
S.W. Doh, J.H. Park, J.H. Suk, H.J. Shon, J.H. Kim and W.D. Hur \\ $R \& D$ Lab., Samwha Electronics Co., Ltd., 211-1, Jangji-Ri, Dontan-Myoun, Hwasung-Gun, \\ Kyoungki-Do, Korea
}

\begin{abstract}
In order to obtain desired electromagnetic propertjes, high initial permeability and good frequency dependance of initial permeability, seeding effects are experimented in $\mathrm{Mn}-\mathrm{Zn}$ ferrite system. As adding seed grain, calcined at sintering temperature, abnormal grains are disappeared clearly, but the density of sintered Mn-Zn ferrite body and initial permeability of this ferrite body are decreased. On the contrary, in case of adding seed grain which were calcined below the calcination temperature of matrix particle, abnormal grains were remain but the initial permeability is increased with proper seed content Compared these results with those of experiments on additive variations, mean particle size controls, sintering conditions, seeding affects on the microstructure of $\mathrm{Mn}-\mathrm{Zn}$ ferrite similarly.
\end{abstract}

\section{Introduction}

Desired magnetic properties of ferrite could be achieved by controlling microstructure. At present the control of particle size distributions, mean particle size, additions of proper additives, optimizing the sintering condition would be employed to obtain desired mechanical and electromagnetic properties. However abnormal grain growth is easily observed in ferrite. The growth of abnormal grain is linearly increased with sintering time and results in pore captivation and broad grain size distribution, consequently inhomogeneity of microstructure can degrade mechanical strength and electromagnetic properties. Especially the frequency dependence of initial permeability and the variations of initial permeability. on induced magnetic field in high permeability $\mathrm{Mn}-\mathrm{Zn}$ ferrite. Much effort has been devoted to investigate the behavior of abnormal grain growth and many ways have been suggested to cope with this problem[1-2]. In particular, large or small particle of seed grains were added to matrix powder in order to increase the number of abnormal grains at initial stage of sintering and then led to fine microstructure or large grain size. Small and uniform grain size is favourable to low power loss material but large grain size is favourable to high permeability materials, Therefore, addition of seed grains is applicable to the control of microstructure in sintering $\mathrm{Mn}-\mathrm{Zn}$ ferrite system.

\section{Experimental Procedure}

In this experiment, $52.15 \mathrm{~mol} \% \mathrm{Fe} \mathrm{O}_{3}, 26.75 \mathrm{~mol} \% \mathrm{MnO}, 21.10 \mathrm{~mol} \% \mathrm{ZnO}$ were mixed with ball mill for $10 \mathrm{hr}$ and calcined at $950^{\circ} \mathrm{C}$ for $2 \mathrm{hr}$. Calcined $\mathrm{Mn}-\mathrm{Zn}$ ferrite materials as a matrix material were milled with attritor to its mean particle size of $1.0 \mu \mathrm{m}$. As for seeding materials, the mixed Powder were calcined at $750^{\circ} \mathrm{C}, 850^{\circ} \mathrm{C}$, $950^{\circ} \mathrm{C}$, $1300^{\circ} \mathrm{C}$ for $2 \mathrm{hr}$ and milled with ring mill to its mean particle size of $0.5 \sim 1.0 \mu \mathrm{m}$ and $5 \sim 10 \mu \mathrm{m}$. This seed grains are added to the matrix material at $0,0.5,1.0,3.0 \mathrm{wt} \%$ and pressed with mechanical hand press. Its green density was $2.25-3.00 \mathrm{~g} / \mathrm{cm}^{3}$. These green bodies were sintered at $1330^{\circ} \mathrm{C}$ for $3,5,7 \mathrm{hr}$ and annealed at $1250^{\circ} \mathrm{C}$ for $2 \mathrm{hr}$. The electromagnetic properties of these toroidal cores were measured with HP 4194A network analyzer. And these properties were compared with those obtained from experiments to the variations of additives, particle size distributions and sintering conditions. And microstructures of these sintered $\mathrm{Mn}-\mathrm{Zn}$ ferrite bodies were observed with SEM photographs after polishing with sand paper and chemical etching. From these results, the effect of seeding in the sintering process could be deduced. Also, relations of microstructures of sintered $\mathrm{Mn}-\mathrm{Zn}$ ferrite body with the electromagnetic properties, initial permeability and frequency dependence were understond. 


\section{Results and Discussion}

The mean particle size of matrix was $1.0 \mu \mathrm{m}$ and those of seed grains were $0.5 \sim 1.0 \mu \mathrm{m}$ and $5 \sim 10 \mu \mathrm{m}$.

In case of adding seed grains calcined at $1300^{\circ} \mathrm{C}$, the abnormal grains were disappeared and then $\mathrm{Mn}-\mathrm{Zn}$ ferrite body had uniform grain size distributions. However, density and grain size were decreased. As a result, initial permeability of this sintered body was much lower than that of specimens without seed grains. But the cut off frequency of initial permeability was increased. By the way, as adding seed grains calcined below the calcination temperature of matrix particles, the abnormal grains were not disappeared. On the contrary, the abnormal grain was much larger than that of specimens without seed grains. Therefore the initial permeability of this sintered body at low frequency was slightly higher than that of specimens without seed grains, and its sintered density was increased with proper seed contents. The cut off frequency of the initial permeability, accordingly, was decreased.

From these results, the added seed grains of small or large particle size, calcined at $1300^{\circ} \mathrm{C}$, retarded densifications by the scaling law. The added seed grains of small or large particle size and calcined below the calcination temperature of matrix particles had slightly higher driving force and assisted densifications at the initial stage of sintering process.

It might be proposed that the calcination temperature of seed grains affects the driving force in the initial stage of sintering(sce Fig.1 b) That is, the seed grain calcined at sintering temperature has thermodynamically lower driving force in the initial stage of sintering, therefore it could be an inhibitor, which resulted in decreasing driving force for densification in the initial stage of sintering and finally retarded densification. But the seed grains calcined at below the temperature of matrix was vice versa.

As we can sce at Fig. 1 a) a certain additive makes it possible to increase the initial permeability with its content only but decrease the cut off frequency of initial permeability. Also another additive can make it possible to increase the cut off frequency of initial permeability with minor change in original initial permeability.

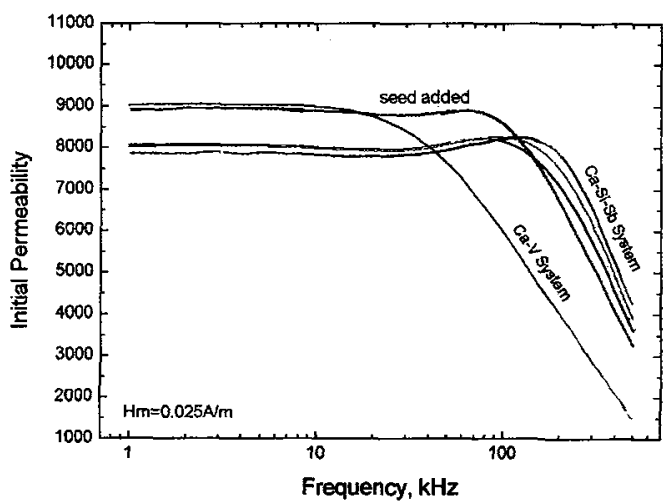

(a)

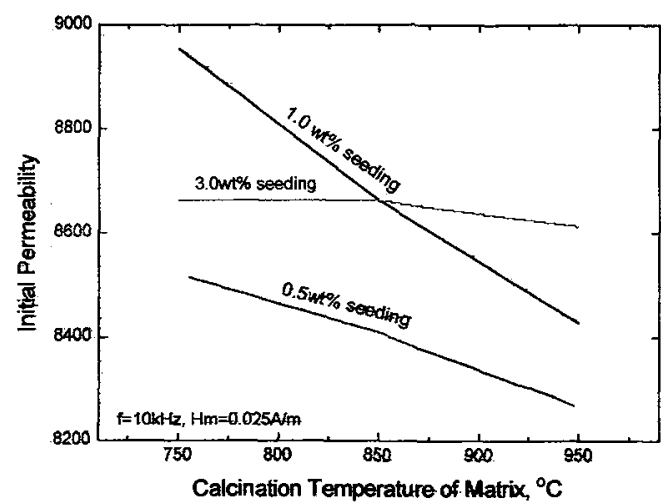

(b)

Fig. I Characteristics of initial permeability (a) Frequency dependence of initial permeability for specimens manufactured at different conditions (b) Initial permeability variations according to calcination temperature of seed grains.

\section{Conclusions}

Seed grains of different particle size and calcined at different temperatures, have different driving force in the initial stage of sintering. Therefore these thermodynamic variations of seed grains could affect the grain growth of $\mathrm{Mn}-\mathrm{Zn}$ ferrite. Microstructural control of $\mathrm{Mn}-\mathrm{Zn}$ ferrite can be achieved by controlling calcination temperature and mean particle size of seed grains. These results can be applied to manufacturing of high permeability $\mathrm{Mn}-\mathrm{Zn}$ ferrite: material.

\section{References}

[1] G.H. Jonker and A.L. stuijts, "Controlling the properties of Electroceramic Mareials Through their Microstructure," Philps Tech. Rev., 32, 79-95, 1971, No. 3/4

[2] S.J. Bennison, "Grain Growth," pp.304-312 in Glasses, Vol. 4 Engineered Materials Handbook Ed. by S.R. Lampman etc., ASM International, 1991

[3] G.R. Chol, "Influence of milled Powder Particle Size Distribution on the microstructure and Electrical Properties of Sintered Mn-Zn Ferrite" J. Am. Ceram. Soc., 54(1), 34-39, 1971. 